\title{
Cold-water coral ecosystem (Tisler Reef, Norwegian Shelf) may be a hotspot for carbon cycling
}

\author{
Martin White ${ }^{1, *}$, George A. Wolff ${ }^{2}$, Tomas Lundälv ${ }^{3}$, Damien Guihen ${ }^{1,6}$, \\ Kostas Kiriakoulakis ${ }^{4}$, Marc Lavaleye ${ }^{5}$, Gerard Duineveld ${ }^{5}$ \\ ${ }^{1}$ Department of Earth and Ocean Sciences, National University of Ireland, Galway, Ireland \\ ${ }^{2}$ School of Environmental Sciences, University of Liverpool, 4 Brownlow Street, Liverpool L69 3GP, UK \\ ${ }^{3}$ Sven Loven Centre for Marine Science, University of Gothenburg, 45296 Strömstad, Sweden \\ ${ }^{4}$ School of Natural Sciences and Psychology, John Moores University, Byrom St., Liverpool L3 3AF, UK \\ ${ }^{5}$ The Royal Netherlands Institute for Sea Research, NIOZ, PO Box 59, 1790 AB Den Burg (Texel), The Netherlands
}

${ }^{6}$ Present address: British Antarctic Survey, High Cross, Maddingley Rd, Cambridge CB2 0ET, UK

\begin{abstract}
Cold-water coral (CWC) reefs are recognised as an important marine benthic ecosystem at continental margins. Where abundant, they most likely play a role both in the maintenance of biodiversity and in the provision of ecosystem services provided by shelf seas. Here, we directly measure the community respiration of a CWC reef on the Norwegian shelf and show that rates of oxygen uptake are high in summer $\left(25-88 \mathrm{mmol} \mathrm{O}_{2} \mathrm{~m}^{-2} \mathrm{~d}^{-1}\right)$, with lower spring values (7.5-9 mmol $\mathrm{O}_{2} \mathrm{~m}^{-2} \mathrm{~d}^{-1}$ ). Spring uptake rates are comparable to values at shelf sediments at similar water depths, while summer values are much higher. We calculate that with such high respiration rates, CWC reef ecosystems potentially turnover a significant proportion ( $25 \%)$ of the annual shelf carbon export in the Norwegian Sea, where CWC reefs are abundant. The loss of CWCs through physical destruction or ocean acidification may have a significant impact on local carbon cycling in the mid- to high-latitude North Atlantic Ocean.
\end{abstract}

KEY WORDS: Benthic community respiration $\cdot$ Cold-water corals $\cdot$ Lophelia pertusa $\cdot$ Carbon cycling

Resale or republication not permitted without written consent of the publisher

\section{INTRODUCTION}

The widespread occurrence of the scleractinid cold-water corals Lophelia pertusa and Madrepora oculata at the European Margin of the Atlantic Ocean has been recognised (Frederiksen et al. 1992, Bett 2001, Freiwald et al. 2002, Duineveld et al. 2004, Davies et al. 2008), while reports of cold water corals (CWCs) continue to increase throughout the world's oceans (Freiwald 2002, Roberts et al. 2006). CWCs are dynamic ecosystems associated with high biomass, species diversity and richness of macro- and megafauna, particularly predators and filter feeders
(Jonsson et al. 2004). Well over 1300 species have been found living on $L$. pertusa reefs in the NE Atlantic (Roberts et al. 2006). There is evidence to suggest that CWC ecosystems have elevated respiration rates compared with different benthic environments at similar depths with no coral present (van Oevelen et al. 2009). Where CWCs are abundant, for example on the Norwegian Shelf (Mortensen et al. 1995, Fosså et al. 2002), they are likely to play an important role both in the maintenance of biodiversity and in the ecosystem services (e.g. provision of fish nurseries and spawning grounds) provided by the shelf seas. 
CWCs are heterotrophic; hence, the ecosystems require an external energy source. At large spatial scales, they have usually been found in waters with high overlying pelagic productivity (Freiwald 2002, White et al. 2005), and where the carbonate chemistry allows the corals to precipitate their aragonite skeleton (Davies et al. 2008). At intermediate spatial scales $(<100 \mathrm{~km}), \mathrm{CWC}$ reefs are found where there is significant pelagic-benthic coupling in regard to the delivery of particulate organic matter (POM) to the reef systems, e.g. around submarine banks (Duineveld et al. 2004, White et al. 2005), along margins where there is enhanced down slope transport (Thiem et al. 2006) and where there are 'hotspots' of near seabed currents which may enhance local POM fluxes (Genin et al. 1986, Frederiksen et al. 1992, White 2007). CWCs seem to thrive where POM nutritional quality is high (Duineveld et al. 2004, 2007, Kiriakoulakis et al. 2004). At the Tisler Reef, carbon fluxes have been found to be high varying between 18 and $1485 \mathrm{mg}$ particulate organic carbon (POC) $\mathrm{m}^{-2} \mathrm{~d}^{-1}$ (1.5 and $123.8 \mathrm{mmol}^{2}$ PC m $\mathrm{m}^{-2} \mathrm{~d}^{-1}$ ), with an average of $459 \mathrm{mg} \mathrm{POC} \mathrm{m}^{-2} \mathrm{~d}^{-1}$ (38.3 mmol POC m $\mathrm{m}^{-2}$ $\mathrm{d}^{-1}$, Wagner et al. 2011). Near seabed suspended POC concentrations at the reef have been measured between 10 and $50 \mu \mathrm{g} \mathrm{l}^{-1}$ (0.83 and $4.2 \mu \mathrm{M} \mathrm{C}$, Lavaleye et al. 2009), 22 and $80 \mu \mathrm{g} \mathrm{l}^{-1}$ (1.83 and $6.7 \mu \mathrm{M} \mathrm{C}$, Wild et al. 2009) and 44 and $106 \mu g l^{-1}$ (3.7 and $8.83 \mu \mathrm{M}$ C, Wagner et al. 2011).

There have been very few studies regarding the role of CWC ecosystems in carbon and nutrient remineralisation. An ecosystem modeling approach for a location $(\approx 800 \mathrm{~m}$ water depth) in the Rockall Trough (west of Ireland) has shown that CWC reefs may have an extremely high carbon uptake/respiration rate (van Oevelen et al. 2009). Respiration rates, measured in vitro, ranged from $1.83 \mathrm{mmol} \mathrm{C} \mathrm{m} \mathrm{m}^{-2} \mathrm{~d}^{-1}$ for the CWC to $13.7 \mathrm{mmol} \mathrm{C} \mathrm{m} \mathrm{C}^{-2} \mathrm{~d}^{-1}$ for the sedimentary community. The ecosystem model led to an estimate for Rockall CWC community respiration of $65 \mathrm{mmol} \mathrm{O}_{2} \mathrm{~m}^{-2} \mathrm{~d}^{-1}$. Only $9 \%$ of the total respiration was due to the coral Lophelia pertusa itself; much of the respiration/uptake was ascribed to other fauna and bacteria, particularly those associated with the dead coral substrate that makes up a large part of the reef structures.

Here, we present estimates of oxygen uptake from a shallow shelf reef located at the Swedish/Norwegian submarine border, based on time series of fixed-point observations of oxygen concentration. Estimates of community respiration have been made with assumptions regarding the likely residence time of the near seabed water over the reef leading to a gross mea- surement for the respiration rate. The values measured at this medium-sized, isolated reef are assessed in the context of the much larger CWC coverage found along most of the Norwegian margin $\left(\sim 2000 \mathrm{~km}^{2}\right.$; van Ovelen et al. 2009), and the likely impact on carbon turnover across the region is examined.

\section{MATERIALS AND METHODS}

The study site was the Tisler CWC reef $(2 \times 0.3 \mathrm{~km})$ centred at $58^{\circ} 59^{\prime} \mathrm{N}, 10^{\circ} 58^{\prime} \mathrm{E}$, at water depths between 70 and $155 \mathrm{~m}$, situated in a channel connecting the deeper Kosterfjord with the northern Skagerrak channels of depths $>250 \mathrm{~m}$ (Fig. 1a, Lavaleye et al. 2009). The reef consists of the numerous colonies of live Lophelia pertusa coral situated on a sill within the channel, surrounded by dead coral rubble and trawl-damaged coral structures. Hydrographic and biogeochemical measurements have been ongoing since 2006 and have included long-term observations of currents, temperature/salinity, oxygen and suspended particulate matter chemistry (Lavaleye et al. 2009).

\section{Oxygen measurements}

Dissolved oxygen concentrations were measured at Tisler Reef during 3 periods between spring 2006 and autumn 2007 using Aanderaa oxygen optodes mounted onto recording current meters RCM9 (Aanderaa) (Table 1, Fig. 1b). All but one of the instruments were placed on the seabed within the reef structure using a Sperre Subfighter remotely operated vehicle (ROV), and measurements were made at a sensor height of $80 \mathrm{~cm}$ above the seabed, which ranged in water depth from 100 to $150 \mathrm{~m}$, with a sampling period that varied between 10 and $30 \mathrm{~m}$ depending on deployment (Table 1). The individual deployments consisted of 2 RCM units located at different positions within the Tisler Reef (Table 1, Fig. 1b). The 3 deployments were: (1) An initial month-long experiment in spring 2006, when the 2 RCMs were located in mid reef near the top, and at the southern flank, of the deeper part of the sill. (2) An early summer redeployment of the instruments towards each end of the reef structure; one to the NW in a channel adjacent to the sill and one to the SE directly below the sill. (3) A long summer-autumn deployment with 1 RCM within a dense cluster of live coral stands and one RCM on a mooring ( $3 \mathrm{~m}$ above bottom) at the extreme SE end of the reef. 


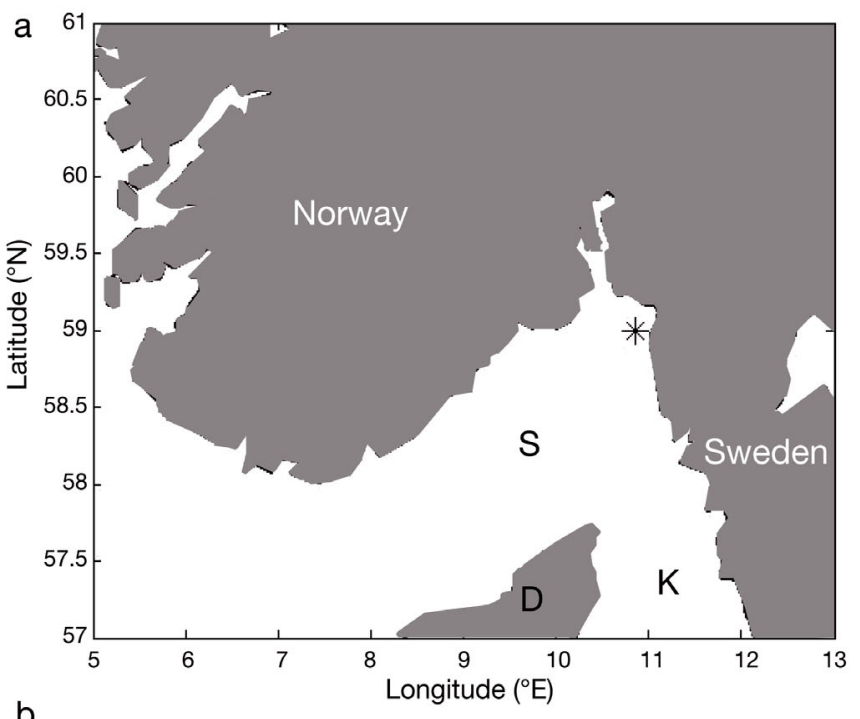

b

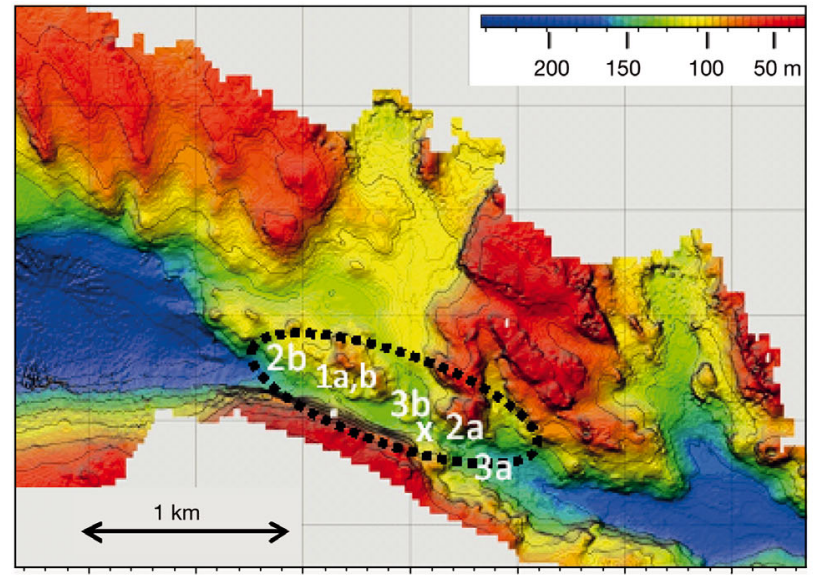

Fig. 1. (a) General location of the Tisler Reef (*) within the northern Skagerrak, together with (b) a higher resolution bathymetry map of the Tisler Reef, showing the approximate extent of the live and associated rubble reef structures (dashed line). Location of the recording current meters (RCM9 with optode sensors are shown by deployment label (Table 1). X marks the location of the $1 \mathrm{MHz}$ acoustic doppler current profiler (ADCP) deployment. In (a) $\mathrm{D}=$ Denmark, $\mathrm{S}=$ Skagerrak, $\mathrm{K}=$ Kattegat
Conventional CTD observations were not available prior to 2008, but vertical profiles of water column parameters (temperature, salinity, oxygen) were obtained from a CTD fixed to the ROV during the 2006 experimental periods. Apparent oxygen utilisation (AOU) values were calculated according to Mecking et al. (2006 and references therein).

\section{Currents}

Data on currents were obtained by the RCM units for all deployments to quantify the near seabed flow at a depth $80 \mathrm{~cm}$ above the seabed, i.e. at a height within the coral stands or equivalent height within the adjacent rubble region. To assess the benthic boundary layer (BBL) flow conditions, a Nortek $1 \mathrm{MHz}$ AquaDopp current profiler with a rightangled head was deployed for $2 \mathrm{~d}$ within the live reef region (August 2008, Table 1). This was the third deployment in a series of high frequency acoustic doppler current profiler (ADCP) measurements to quantify the nature of the seabed shear stress and boundary layer conditions within and outside the living reef environment, as discussed by Guihen (2010) and D. Guihen et al. (unpubl.). A profile of currents, extending $15 \mathrm{~m}$ above the seabed and with vertical resolution of $0.5 \mathrm{~m}$, was obtained by the instrument with a sampling period of $10 \mathrm{~min}$.

\section{Respiration estimates}

The oxygen measurements were Eulerian (i.e. made at a fixed point over time) and, therefore, measured both changes in situ and those advected from 'upstream' in terms of the local current regime. In this study, a measurement of the gross reef community respiration was obtained by diagnosing the vari-

Table 1. Details of the recording current meter (RCM) and acoustic doppler current profiler (ADCP) deployments made to measure near seabed currents and oxygen at Tisler Reef and short description of relative position within the reef structure.

Dates given as dd/mm/yy. RCM deployments: 1a, 1b, 2a, 2b, 3a, 3b; ADCP deployment A

\begin{tabular}{|llcccccl|}
\hline $\begin{array}{l}\text { Deploy. } \\
\text { no. }\end{array}$ & $\begin{array}{l}\text { Time } \\
\text { period }\end{array}$ & Lat. & Long. & $\begin{array}{c}\text { Start } \\
\text { day }\end{array}$ & $\begin{array}{c}\text { End } \\
\text { day }\end{array}$ & $\begin{array}{c}\text { Depth } \\
(\mathrm{m})\end{array}$ & Location \\
\hline 1a & Spring 06 & 58.9975 & 10.9612 & $31 / 03 / 06$ & $28 / 04 / 06$ & 102 & Mid reef, top sill \\
1b & Spring 06 & 58.9970 & 10.9607 & $31 / 03 / 06$ & $25 / 04 / 06$ & 120 & Mid reef, channel \\
2a & Early Sum 06 & 58.9973 & 10.9584 & $05 / 05 / 06$ & $24 / 07 / 06$ & 132 & SE end of reef below sill \\
2b & Early Sum 06 & 58.9946 & 10.9733 & $05 / 05 / 06$ & $17 / 06 / 06$ & 150 & NE end reef, channel \\
3a & Sum/Aut 07 & 58.9942 & 10.9745 & $29 / 04 / 07$ & $06 / 11 / 07$ & 119 & Extreme SE fringe of reef \\
3b & Sum/Aut 07 & 58.9956 & 10.9663 & $29 / 04 / 07$ & $04 / 11 / 07$ & 118 & Central reef on sill \\
A & Sum 08 & 58.9964 & 10.9680 & $02 / 08 / 08$ & $04 / 08 / 08$ & 115 & 1 MHz ADCP within live reef on sill \\
\hline
\end{tabular}


ation of oxygen concentration over the reef as a function of residence time of the water over the reef; the latter was determined by the advection speed of the water passing over the reef. Whilst the sampling rate of the RCM optodes was either 10 or 20 min, daily averaged values of oxygen and flow speed were used for calculations. This was (1) to provide a measurement period long enough to obtain a measurable effect, and (2) to average any tidal or diurnal process that may influence variability in oxygen. Where near bottom water passed over the reef quickly, the point measurement of oxygen would not show a significant change in any background variation (Fig. 2a). As residual flow diminished, water was present over the reef for longer periods of time since the overall flow was insufficient to 'flush' the water away from the reef. We hypothesised that, in the absence of changes in oxygen values due to the advection of different water masses over the reef, a larger difference in oxygen values between long and short residence times would have resulted as oxygen was depleted by the reef community (Fig. 2b). This argument assumes that the high-biomass reef respires at a significantly greater rate than the surrounding benthic environment (van Oevelen et al. 2009). If this was not the case, then oxygen uptake would not vary with a change in the local flow speed (residence time over the reef).

The residual flow over the reef is driven by horizontal water mass density differences across the reef and underlies the periodic tidal flow driving longterm (>day) flow. Maximum values for oxygen deple-
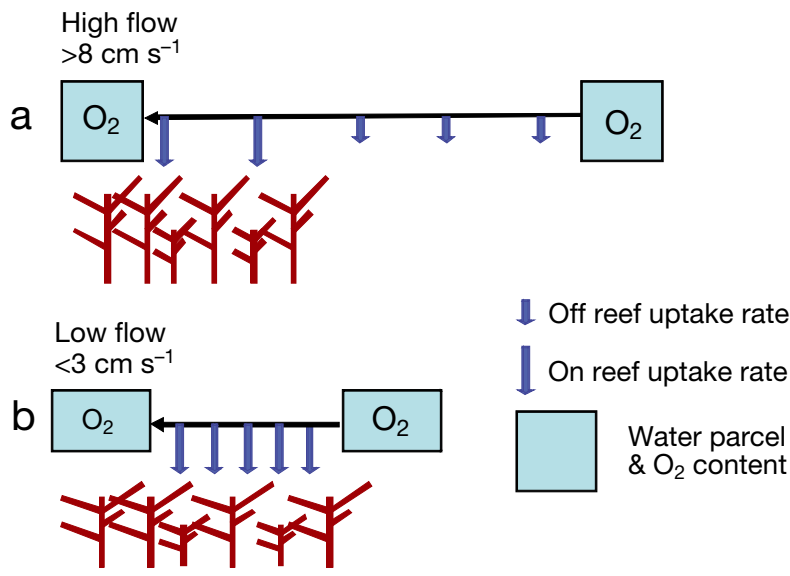

Fig. 2. Sketch showing the concept for the estimation of respiration rates. Boxes are fluid parcels advected right to left (black arrow) over the reef to an end measurement point over a $24 \mathrm{~h}$ period. Blue arrows indicate uptake of oxygen at different rates (arrow size) off and over reef. The regular spacing of the arrows represents equal time periods, such that a closer spacing represents lower flow speeds tion over any averaging period would have coincided with zero residual flow when water was over the reef for the maximum duration within an averaging period of $24 \mathrm{~h}$. A dependence on initial location over the reef would also have influenced the oxygen variation (e.g. flow approaching the in-reef measurement point from 'upstream' of the reef would spend a shorter time over the reef). The difference between daily averaged low flow oxygen (maximum time over reef up to $24 \mathrm{~h}$, the averaging period) and high residual flow oxygen values (minimum time over the reef), therefore, provides a gross estimate of the potential respiration during the water residence time over the reef.

To calculate the difference in oxygen values between high and low flow regimes, the mean of the lowest third of all oxygen values found with absolute daily averaged flow $<3 \mathrm{~cm} \mathrm{~s}^{-1}$ was subtracted from mean value of all points for daily averaged flow $>8 \mathrm{~cm} \mathrm{~s}^{-1}$. For the shorter spring measurements, when water mass exchanges across the reef creating a background change (offset) in oxygen values were largely absent, absolute $\mathrm{O}_{2}$ concentrations could be used in the calculation. For the longer summer measurements, however, background oxygen values probably changed due to variation in water masses moving into the region as well as the overall background depletion in oxygen that would be expected in the sub-thermocline region due to biological activity. Therefore, anomalies were used, generated by subtracting the long-term trend in oxygen variation over time. This difference provides a quantitative, conservative estimate for the oxygen utilisation, which averages out some shorter-term variability and, therefore, has some degree of error associated with it. The use of 2 instrument locations allowed some estimate of the variability of oxygen ultilisation within different CWC reef locations (differing habitats) and allowed an estimation of error in the utilisation measurements.

\section{RESULTS}

\section{Currents and BBL characteristics}

Hydrodynamics at the Tisler Reef are characterised by weak semi-diurnal tidal constituent $\left(M_{2}\right)$, and relatively large sub-tidal currents that exchange water over a sill through a SE-NW-orientated channel connecting Kosterfiord and the Skagerrak (Lavaleye et al. 2009, Guihen 2010). Both tidal and sub-tidal (residual) flow is dominated by the along-channel compo- 
nent due to the constricted nature of the sill region, so only the NW component of velocity will be shown in this paper. A representative $(\sim 100 \mathrm{~d})$ portion of near seabed along-sill current (RCM deployment 3a, Table 1), showing typical flow characteristics, is depicted in Fig. 3a. Tidal current amplitude, calculated from a least squares analysis, varied between 3 and $8 \mathrm{~cm} \mathrm{~s}^{-1}$ for neap and spring tidal conditions, respectively (Fig. 3b). However, residual flow magnitude could be larger, usually up to $25 \mathrm{~cm} \mathrm{~s}^{-1}$, but with short periods of much higher speeds (Fig. 3c, Guihen 2010). Flow reversals were generally associated with the appearance of different water masses driven by large-scale atmospheric forcing, or by changes in the water column density (Lavaleye et al. 2009).

Weak tidal currents were significant for movement of water over the reef, because the associated tidal excursion, the horizontal movement of water in an ellipse during one tidal cycle, does not exceed the length of the reef. A first order estimate for the tidal excursion amplitude is given by:

$$
2 \times V_{0} \times T / 2 \pi
$$

where $T$ is the semi-diurnal tidal period (s) and $V_{0}$ the tidal velocity amplitude $\left(\mathrm{cm} \mathrm{s}^{-1}\right)$. For a $V_{0}$ between 3 and $8 \mathrm{~cm} \mathrm{~s}^{-1}$, therefore, an excursion ranging from $\sim 450 \mathrm{~m}$ to $1200 \mathrm{~m}$ is expected, which is less than the along-sill extent of the reef. As a result, tidal currents are unable to 'flush' the reef during one $M_{2}$ tidal cycle in the absence of any residual flow. During periods of low residual flow, therefore, the residence time of water in the benthic boundary layer over the reef may increase significantly. In the absence of significant tidal flushing, a residual flow of $\sim 5 \mathrm{~cm} \mathrm{~s}^{-1}$ is required to advect water across the entire reef during one $M_{2}$ tidal cycle.

Observations by Guihen (2010) and D. Guihen et al. (unpubl.) have shown that live coral stands at the sill are typically 1 to $2 \mathrm{~m}$ high and generate a relatively thick benthic boundary layer compared to adjacent regions of relatively flatter topography of the dead coral rubble. Observations of the near seabed current using a $1 \mathrm{MHz} \mathrm{ADCP}$ within the reef structure suggested a boundary layer, where the vertical current amplitude varied logarithmically, of up to $12 \mathrm{~m}$ from the seabed (Fig. 4), similar to that measured in an
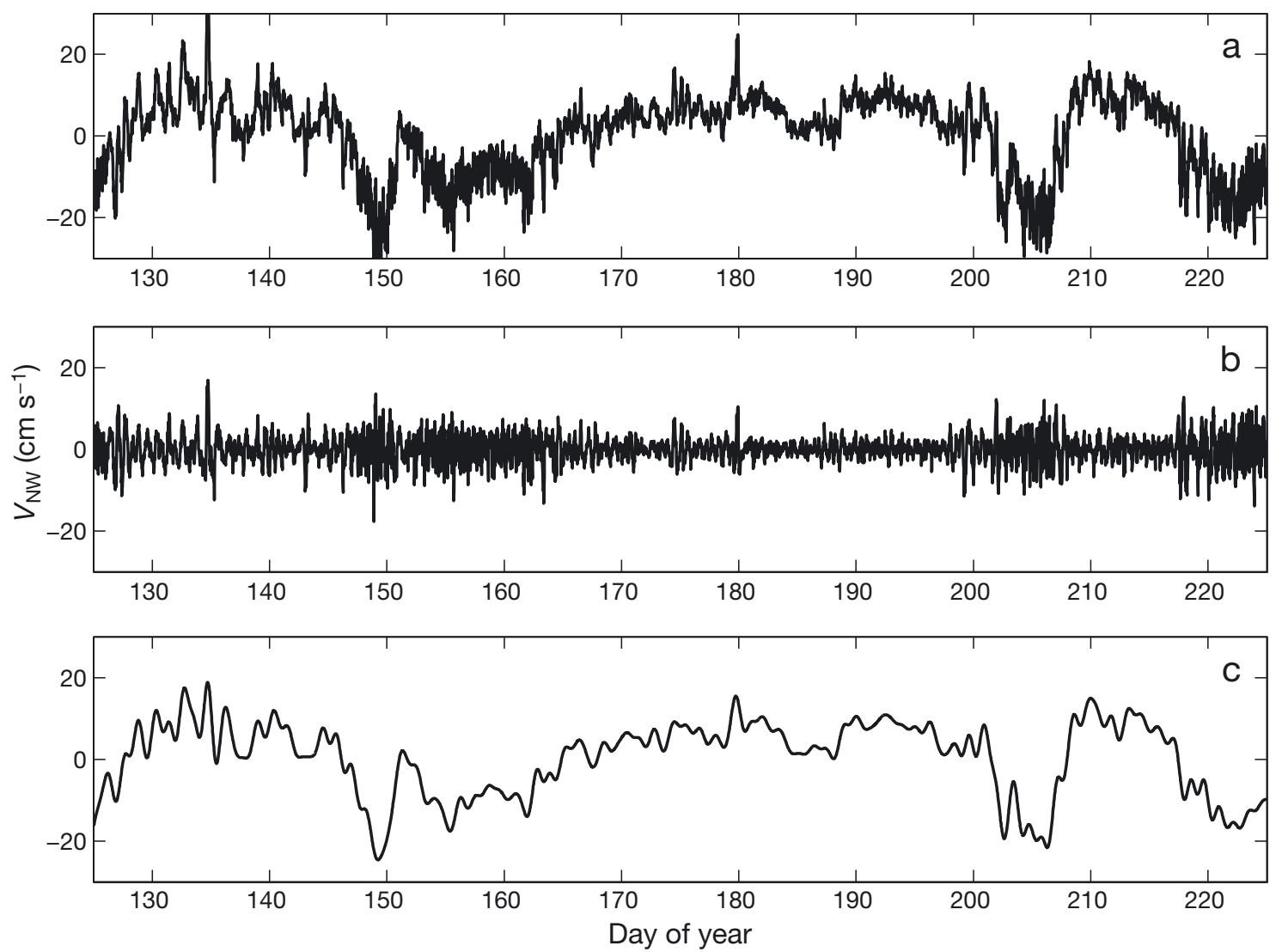

Fig. 3. Time-series of (a) NW component of velocity $\left(V_{\mathrm{NW}}\right)$ at $80 \mathrm{~cm}$ above seabed from within the reef during summer 2007 and (b) high pass and (c) low pass (cut off period $27 \mathrm{~h}$ ) for the same data set shown in (a) 


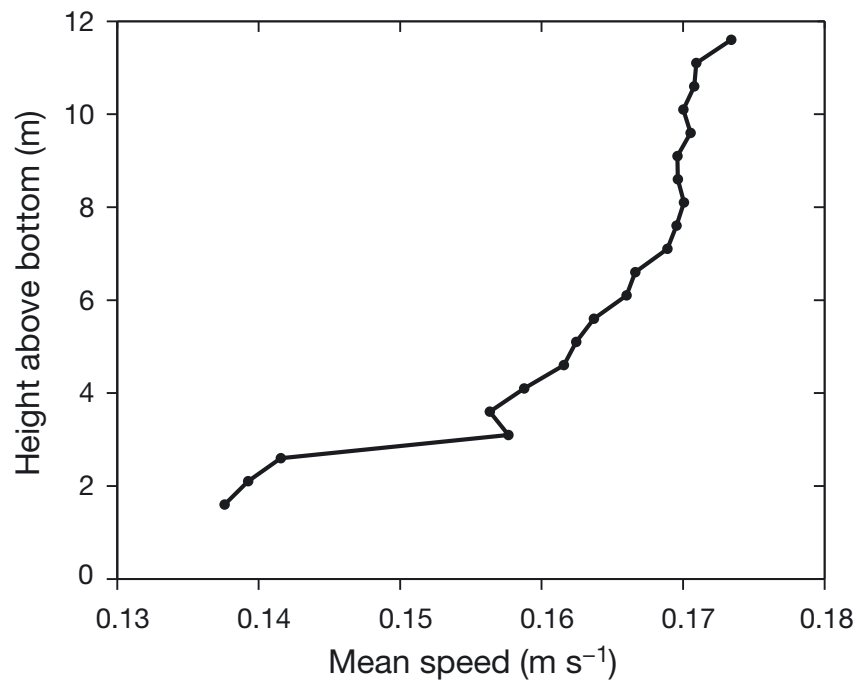

Fig. 4. Mean vertical profile of horizontal current speed within a live coral reef from a $58 \mathrm{~h}$ deployment $(02: 30 \mathrm{~h}$ on 2 August 2008 to $12: 30 \mathrm{~h}$ on 4 August 2008) of a $1 \mathrm{MHz}$ acoustic doppler current profiler (ADCP) within the main reef structure (D. Guihen et al. unpubl.)

earlier experiment (D. Guihen et al. unpubl.). The boundary layer showed temporal variability, typically between 2 and $12 \mathrm{~m}$ and extended to a height greater than that inferred over the rubble region using the same technique $(\sim 1-5 \mathrm{~m})$. The mean velocity profile (Fig. 4), indicated disruption of this boundary layer in the lower $3 \mathrm{~m}$ of the water column, where the values of current speed did not demonstrate the typical logarithmic vertical structure. This corresponded to a height of $1.5-2 \times$ the coral reef height, and we infer that the presence of coral creates a more uniform boundary layer in the lower $3 \mathrm{~m}$, where the flow amplitude decreased significantly within the corals. It is suggested, therefore, that measurements of both currents and oxygen by the RCMs sensors at $80 \mathrm{~cm}$ above the seabed, a height within the extension of the physical reef from the seabed, are representative of the lower $3 \mathrm{~m}$ of the water column, given the likely reduction in flow within the live coral stands and the mean boundary layer height above the live coral and rubble regions of the Tisler Reef.

\section{Oxygen measurements}

ROV CTD profiles, made in May 2006, prior to the early summer measurement period, revealed a typical water column structure for the region (Fig. 5). Hence, as measured in April 2006 (not shown), a relatively warm, fresh surface layer of $\sim 20 \mathrm{~m}$ was found, where oxygen concentrations were supersatu- rated. Below the thermocline/pycnocline, temperatures decreased with depth to a minimum at 40 to $50 \mathrm{~m}$ and then rose below that and became more uniform in the lower $20 \mathrm{~m}$ of the water column. Similarly, salinity increased steadily with depth below the halocline to typical shelf values of $\sim 34.6$. Oxygen saturation decreased with depth to a minimum of $\sim 91 \%$ at $70 \mathrm{~m}$, where a small temperature maximum was found, below which values increased slowly to more uniform near-seabed layer with values of 92 to $93 \%$. AOU values varied inversely with oxygen saturation, from surface layer negative values to relatively uniform values of 23 to $24 \mu \mathrm{M}$ in the lower $20 \mathrm{~m}$ of the water column.

A time-series of daily averaged oxygen concentrations from all measurements made in 2006 and 2007 provide an overall picture of the seasonal variability in oxygen concentration for those years (Fig. 6a). Different time-series from single deployment periods of instrument pairs show offsets due to the depth variation of the sensor deployments and possibly due to the relative location of each instrument pair. Highest oxygen concentrations occurred in early spring after the winter renewal of deep fjordic water and decreased thereafter for the time of measurements (April-November) in a similar way to the seasonal pattern observed in the shallow parts of the Skagerrak and Kattegat waters (Andersson \& Rydberg 1988, 1993). As well as the overall decrease in oxygen concentration from May to November $\left(\sim 60 \mu \mathrm{mol} \mathrm{l}^{-1}\right.$ in $\sim 200 \mathrm{~d})$, the time-series was punctuated by short (1-4 d) periods of much reduced oxygen concentrations, which subsequently returned back to previous concentration levels. These periods of relatively low oxygen concentrations were more frequent in the latter part of the summer.

To assess the intra-reef variability in oxygen concentration, data from each individual instrument pair were compared (Fig. 6b). Overall, oxygen values measured coincidently at 2 site locations at any time corresponded well and showed a linear relationship offset from a 1:1 regression due to the different depth of measurement (and possibly absolute calibration differences). Two exceptions were noted. During measurements (Deployments 2a, 2b; Table 1) made at the 2 ends of the reef in early summer 2006, a water mass exchange event occurred which was identified by only one instrument. Secondly, a few outliers were observed during the long 2007 deployment $(3 \mathrm{a}, 3 \mathrm{~b})$ made at the centre and edge of the reef. Nevertheless, the general correspondence between each pair of instruments for a single measurement period does lend confidence that variations in oxy- 

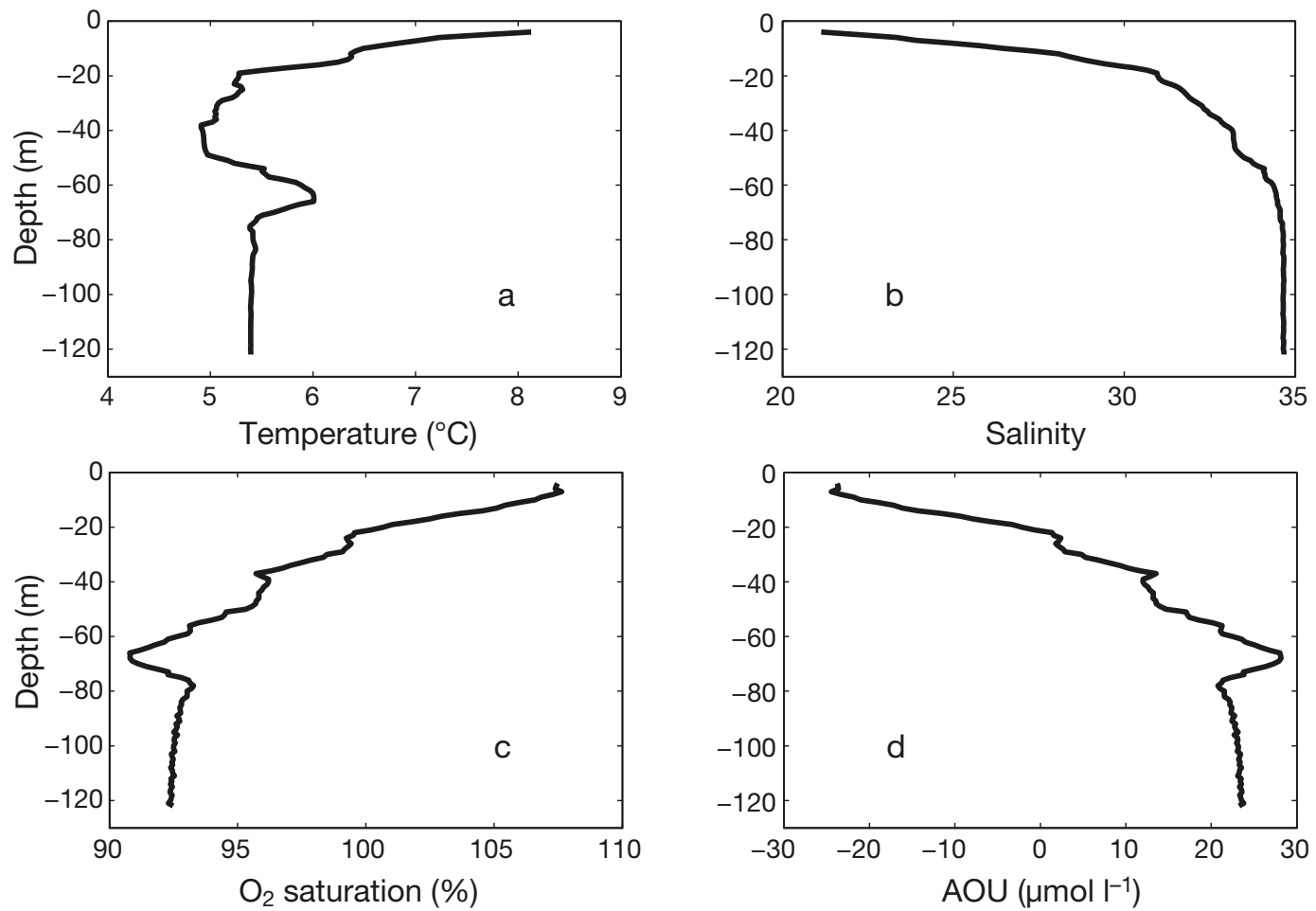

Fig. 5. Vertical profiles of (a) temperature, (b) salinity, (c) oxygen saturation and (d) apparent oxygen utilisation (AOU) made with a CTD attached to the remotely operated vehicle (ROV) during a dive to the Tisler Reef, 27 May 2006
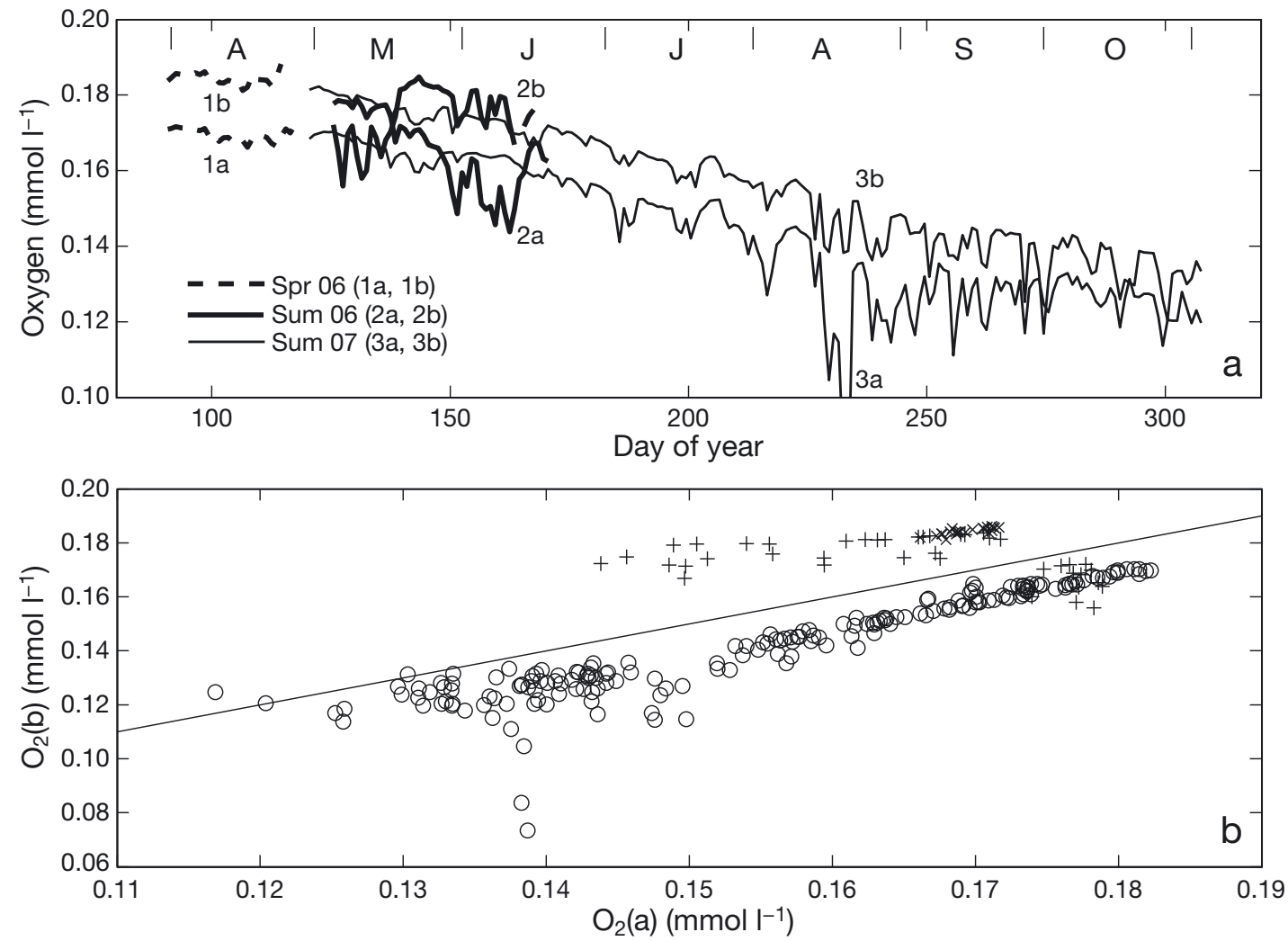

Fig. 6. (a) Time-series of daily averaged oxygen for all 3 experiments during spring 2006 to autumn 2007. Different deployment periods (Table 1) are labelled. In (b) the pair of oxygen measurements made for each individual deployment (labelled a and $b$, respectively, on axes) is shown for: $(\times) 1 \mathrm{a}, 1 \mathrm{~b} ;(+) 2 \mathrm{a}, 2 \mathrm{~b}$; and (O) $3 \mathrm{a}, 3 \mathrm{~b}$ 

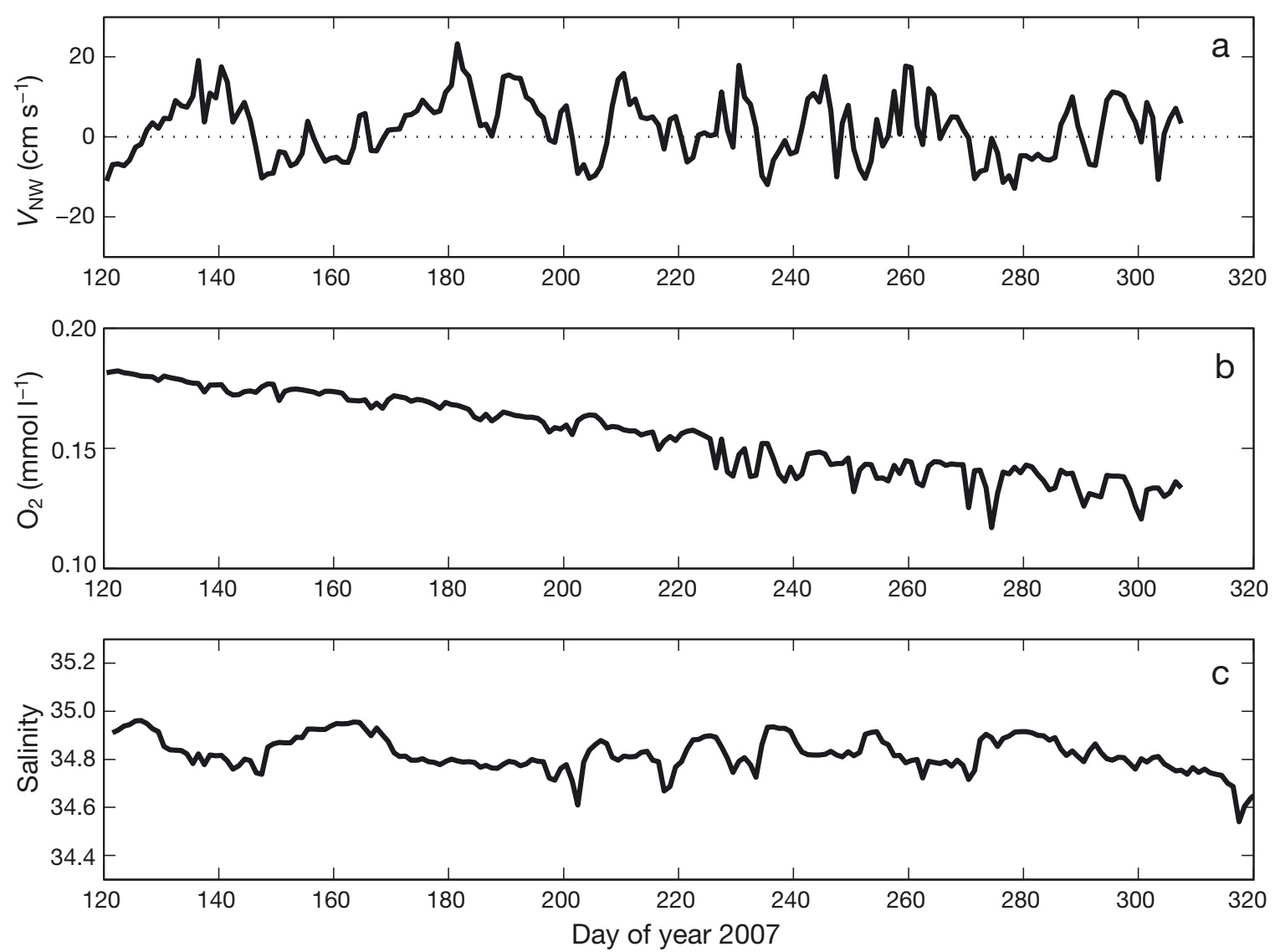

Fig. 7. Time-series of (a) NW velocity component ( $\left.V_{\mathrm{NW}}\right)$, (b) oxygen (mmol $\mathrm{l}^{-1}$ ) for Deployment $3 \mathrm{~b}$ made at mid reef, and (c) salinity from a bottom-mounted Sbe37 sensor deployed close to the $3 \mathrm{~b}$ site

gen concentration, the basis for our respiration estimates, were similar across the whole reef system.

A time-series of along-sill (NW) flow and oxygen concentration data from one of the long deployments (3a, mid reef) is shown in Fig. 7, together with a timeseries of salinity from a conductivity and temperature sensor (Sbe37 microCAT) deployed on a bottom frame close to the RCM. Variability in oxygen over long time periods was observed, which was related to changes in mean flow direction and likely water mass exchange over the reef. In the initial $80 \mathrm{~d}$ of deployment, daily averaged flow direction changed only 3 times and the majority of the time, a mean NW flow of magnitude up to $20 \mathrm{~cm} \mathrm{~s}^{-1}$ was observed. Lower salinities were associated with the NW flow, indicating flow of the fresher inner Kosterfiord water into the open Skagerrak. After Day 200, an increased occurrence of lower $\left(<5 \mathrm{~cm} \mathrm{~s}^{-1}\right)$ mean residual flow amplitude events was identified, together with a number of short period flow reversals. Jumps in the salinity were associated with these reversals. The periods of low residual flow coincided with drops in oxygen concentration (e.g. Days 225-230, Day 255).
A variation of oxygen concentration with flow speed over the reef was apparent (Fig. 8). At high along-channel flow speeds $\left(>8 \mathrm{~cm} \mathrm{~s}^{-1}\right)$, oxygen values remained essentially constant. In general, for mean daily averaged velocities below $\sim 5 \mathrm{~cm} \mathrm{~s}^{-1}$ they decreased with flow speed and minimum oxygen values occurred at, or close to, zero residual flow speed. An exponential power law, of the form $y=$ $a \cdot e^{b x}$, was fitted to each individual measurement set. Whilst there was a variation in the $\mathrm{r}^{2}$ values found for each fit, all regressions were significant at $\mathrm{p}<0.05$. The $\mathrm{r}^{2}$ values were lowest for the longer data summer sets of $188 \mathrm{~d}$ and was likely due in part to the inaccuracy of taking the long term oxygen decline trend. In addition, errors associated with changes in water mass, and hence background absolute oxygen values, will have caused the increased scatter in the relationship as reflected in the low $\mathrm{r}^{2}$ values. The variation was also consistent with the likely differences in the residence times of the water over the reef of between 0 and $24 \mathrm{~h}$ for the daily averaging period, dependant on the residual flow. Sources of error/offset related to short term variability resulted 

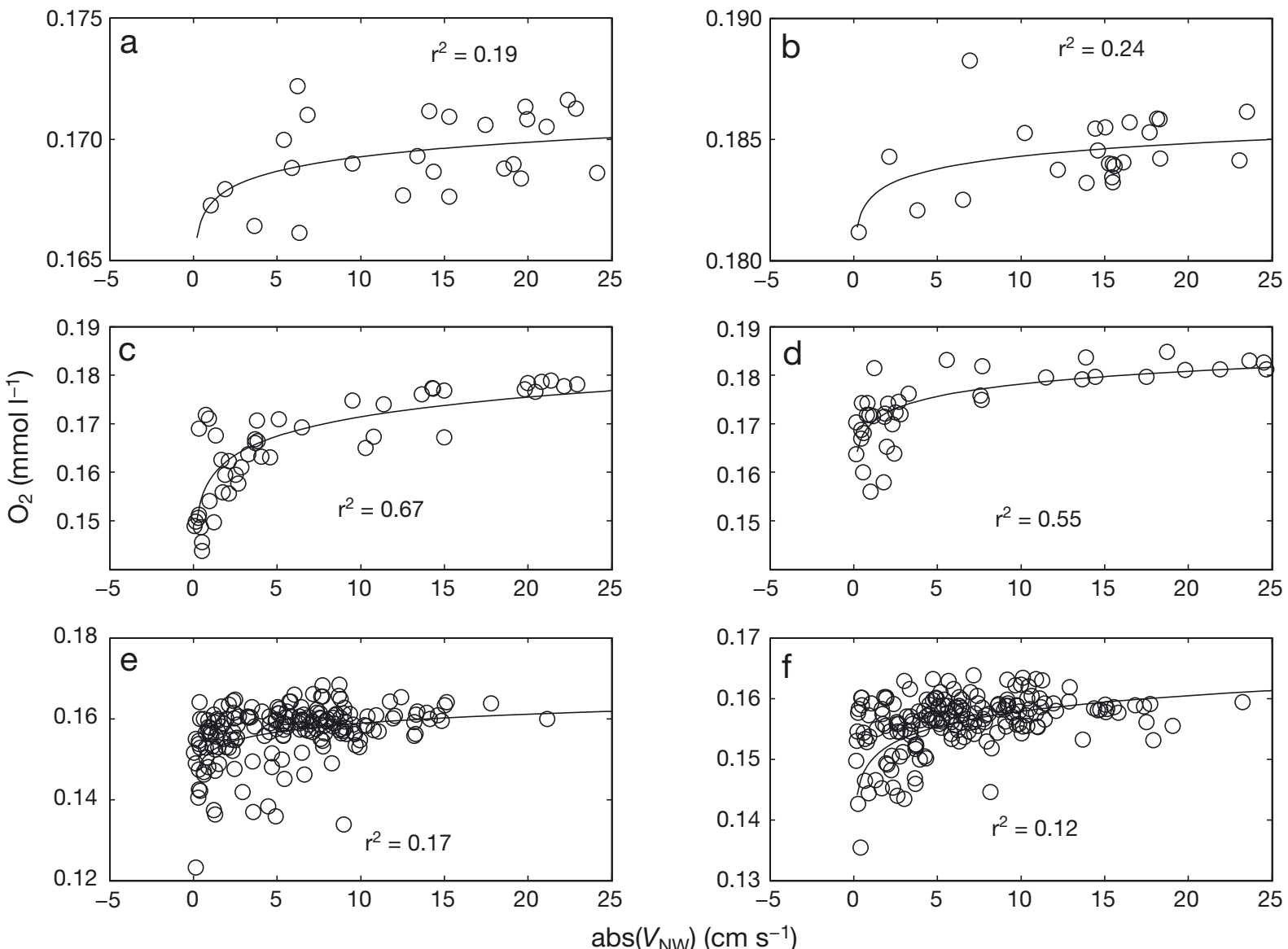

Fig. 8. Oxygen concentration as a function of absolute along-sill (+NW) velocity ( $\left.V_{N W}\right)$ for Deployments (a) $1 \mathrm{a}$, (b) $1 \mathrm{~b}$, (c) $2 \mathrm{a}$, (d) $2 b$, (e) $3 a$ and (f) $3 b$. A best fit curve for a power law of the form $y=a x^{b}$ is shown for each panel

from aperiodic processes, such as the passage of water mass boundaries over the reef and the measurement location within the reef in relation to the mean direction of flow. These errors resulted in relatively high values being recorded at low residual flow, hence the low flow oxygen value was calculated from the mean of the lowest $1 / 3$ of the data found within the flow range $<3 \mathrm{~cm} \mathrm{~s}^{-1}$.

The spring deployment (Deployments 1a, 1b, Fig. 8a,b) was short, $<1 \mathrm{mo}$, and occurred just before the onset of the spring bloom, which occurred relatively late in 2006 (Lavaleye et al. 2009). The power law relationship is not strong, due in part to the limited number of points falling under low flow conditions; flow was topographically steered along the edge of the shallower portion of the reef. The postspring bloom observations in early summer 2006 (Deployments 2a, 2b, Fig. 8c,d) displayed a strong relationship between oxygen concentrations and flow magnitude, perhaps as a response to the prior flux of organic material to the reef that coincided with low flow conditions. Data for the long deploy- ment were split into 2 periods of $84 \mathrm{~d}$ and $104 \mathrm{~d}$ (late summer-autumn), based on the change in flow and oxygen variability characteristics (Fig. 7). Increased scatter was present in this data, due in part to the subtraction of the long-term oxygen variation and because of the likelihood of some smaller water mass exchanges being missed. Again, this resulted in a number of relatively high oxygen concentrations at low flow conditions and generated a source of error in our calculations.

The daily averaged difference between low and high residual flow oxygen values were used to calculate the potential oxygen uptake at the reef (Table 2). Furthermore, to convert the depletion measured per unit volume $\left(\mathrm{l}^{-1}\right)$ value to per unit area $\left(\mathrm{m}^{-2}\right)$ value, the oxygen data was assumed to be representative for the lower $3 \mathrm{~m}$ in the benthic boundary layer as discussed in the currents and BBL characteristics section (Fig. 4). Values varied among the deployments, representing different periods between spring and autumn, but these differences were greater than the estimated error in the calculated uptake rates. Spring 
Table 2. Community oxygen respiration rates determined from the 3 deployments, with 2 recording current meters (RCMs) per deployment. Estimates from the 3rd deployment are split into an initial $84 \mathrm{~d}$ and a second $104 \mathrm{~d}$ period (see 'Results: Oxygen measurements'). Equivalent carbon rates are given assuming a Redfield ratio of $138 \mathrm{~mol} \mathrm{O}_{2}: 106 \mathrm{~mol} \mathrm{C}$

\begin{tabular}{|lccc|}
\hline $\begin{array}{l}\text { Deploy. } \\
\text { no. }\end{array}$ & $\begin{array}{c}\text { Difference } \\
\left(\mathrm{mg} \mathrm{l}^{-1}\right)\end{array}$ & $\begin{array}{c}\mathrm{O}_{2} \\
\left(\mathrm{mmol} \mathrm{m}^{-2} \mathrm{~d}^{-1}\right)\end{array}$ & $\begin{array}{c}\mathrm{C} \\
\left(\mathrm{mmol} \mathrm{m}^{-2} \mathrm{~d}^{-1}\right)\end{array}$ \\
\hline 1a & $0.08 \pm 0.04$ & $7.5 \pm 3.7$ & $5.8 \pm 2.9$ \\
1b & $0.1 \pm 0.03$ & $9.4 \pm 2.8$ & $7.2 \pm 2.2$ \\
2a & $0.86 \pm 0.21$ & $80.5 \pm 19.7$ & $61.8 \pm 15.1$ \\
2b & $0.6 \pm 0.2$ & $56.2 \pm 18.7$ & $43.1 \pm 14.4$ \\
3a_1 & $0.11 \pm 0.07$ & $10.3 \pm 6.6$ & $7.9 \pm 5$ \\
3b_1 & $0.25 \pm 0.09$ & $23.4 \pm 8.4$ & $18 \pm 6.5$ \\
3a_2 & $0.48 \pm 0.2$ & $44.9 \pm 18.7$ & $34.5 \pm 14.4$ \\
3b_2 & $0.94 \pm 0.23$ & $88 \pm 21.5$ & $67.6 \pm 16.5$ \\
\hline
\end{tabular}

values (Deployment 1a, 1b) were 7.5-9.4 $\mathrm{mmol} \mathrm{m}^{-2}$ $\mathrm{d}^{-1}$, but were considerably higher immediately after the spring bloom $\left(56-80 \mathrm{mmol} \mathrm{m}^{-2} \mathrm{~d}^{-1}\right)$. For the long deployment, split into 2 periods of 84 and $104 \mathrm{~d}$ respectively, there were mid-range values in summer $\left(10-23 \mathrm{mmol} \mathrm{m}^{-2} \mathrm{~d}^{-1}\right)$, but higher values in later summer and autumn (45-80 $\mathrm{mmol} \mathrm{m}^{-2} \mathrm{~d}^{-1}$ ). These oxygen consumption values were converted to a mean carbon equivalent value, assuming that carbon respiration had Redfield stoichiometry $\left(138 \mathrm{~mol}\right.$ of $\mathrm{O}_{2}$ : $106 \mathrm{~mol}$ of $\mathrm{C}$ ). Equivalent carbon respiration rates

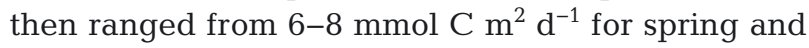
34-68 mmol C m ${ }^{2} \mathrm{~d}^{-1}$ for summer measurements, respectively.

\section{DISCUSSION}

The overall magnitude and variability in the oxygen values found at Tisler Reef are to be expected for a region influenced by the circulation in the deeper portion of the Skagerak and by seasonal processes. Near seabed oxygen saturation values of 90 to $95 \%$ (Fig. 5) are typical for the deep region of the open Skagerak and for that of a water column isolated by the seasonal halocline (e.g. Ljøen 1962). Typically, maximum values in oxygen occur between January and March after winter renewal of water from North Sea inflow; oxygen values are twice the magnitude in winter relative to summer (Andersson \& Rydberg 1993). Oxygen values measured here (Figs. 6 \& 7) decreased from a maximum in March/April to the cessation of our measurements in November. This is attributed to the supply and decay of organic matter to the sub-halocline waters. The rate of decrease did slow during autumn, consistent with the seasonal minimum typically found in September/October in shallower waters (Andersson \& Rydberg 1993). In addition to periods of reduced oxygen due to slow flow conditions, the overall trend of decreasing oxygen over the summer was punctuated by aperiodic shifts in oxygen concentration, which was related to advection of different water masses across the region and an associated horizontal oxygen gradient (e.g. Lavaleye et al. 2009),

The estimates of bulk community oxygen/carbon respiration at the Tisler Reef are high when compared to those of sediment oxygen consumption (SOC) in shelf sea locations, made using a variety of methods. For example, shipboard incubation measurements gave a range of SOC of between 3 and $29 \mathrm{mmol} \mathrm{O} \mathrm{m}^{-2} \mathrm{~d}^{-1}$ for depth ranges $360 \mathrm{~m}$ to $4.2 \mathrm{~m}$ on the New Zealand continental shelf (Giles et al. 2007). Mean variation of SOC with depth for this data set was given by:

$$
\begin{gathered}
\text { SOC }\left(\mu \mathrm{mol} \mathrm{m}{ }^{-2} \mathrm{~h}^{-1}\right)= \\
1222.8-\left(456.3 \times \log _{10}[\text { depth }]\right)
\end{gathered}
$$

When this data was extended to other published SOC rates from many global locations down to depths of $250 \mathrm{~m}$, the SOC (depth) relationship was modified to:

$$
\begin{gathered}
\operatorname{SOC}\left(\mu \mathrm{mol} \mathrm{m}{ }^{-2} \mathrm{~h}^{-1}\right)= \\
1280-\left(418.2 \times \log _{10}[\text { depth] })\right.
\end{gathered}
$$

Historical deck incubation SOC data, together with direct benthic lander measurements, have shown a similar relationship (e.g. Andersson et al. 2004). To account for a depth dependency for deposition rates, Andersson et al. (2004) used a double exponential function to describe the uptake flux as:

$$
F(z)=F_{0}\left[(1-p) \times \mathrm{e}^{-a z}+p \times \mathrm{e}^{-b z}\right] \mathrm{mmol} \mathrm{m}{ }^{-2} \mathrm{~d}^{-1}
$$

where the constants were determined as $F_{0}=$ $38 \mathrm{mmol} \mathrm{m} \mathrm{m}^{-2} \mathrm{~d}^{-1}, p=0.17$, and length scales $a=$ $0.018 \mathrm{~m}^{-1}$ and $b=0.00046 \mathrm{~m}^{-1}$.

The relationships given by Eqs. (3) \& (4) are shown in Fig. 9, together with van Oevelen et al.'s (2009) estimate for a Rockall Bank CWC reef at 800 m water depth, uptake rates and errors. For the Tisler Reef ( 120 m water depth), SOC rates of 9.75 and 9.85 mmol $\mathrm{O}_{2} \mathrm{~m}^{-2} \mathrm{~d}^{-1}$ would be expected from Eqs. (3) \& (4), respectively, namely in the range of our spring and mid-summer respiration rates at the reef $(7.5-23$ $\mathrm{mmol} \mathrm{O}_{2} \mathrm{~m}^{-2} \mathrm{~d}^{-1}$ ). However, post-bloom and autumn values of $45-88 \mathrm{mmol} \mathrm{O}_{2} \mathrm{~m}^{-2} \mathrm{~d}^{-1}$ were significantly larger than predicted by the 2 empirical relationships. Furthermore, the values found here for the Tisler Reef are comparable to that found in the food 


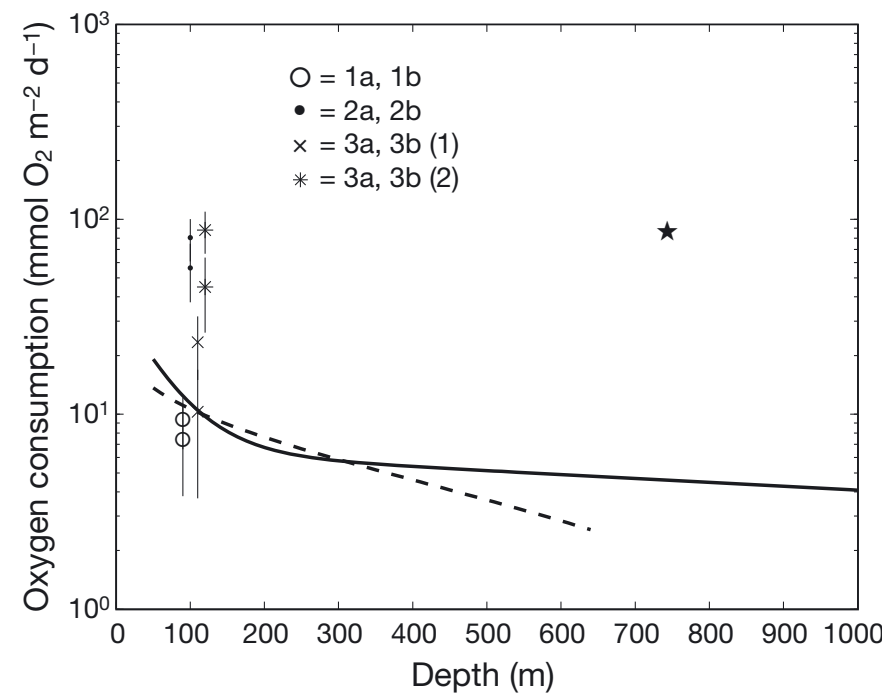

Fig. 9. Variation in sediment oxygen consumption with depth as found from empirical fit to data from (-) Andersson et al. (2004) and (-- -) Giles et al. (2007). Data found for Deployments (O) 1a, 1b; $(\bullet) 2 \mathrm{a}, 2 \mathrm{~b}_{i}(\times) 3 \mathrm{a}, 3 \mathrm{~b}(1$ st $84 \mathrm{~d})$, and (*) 3a, 3b (2nd $104 \mathrm{~d}$ ) are shown with corresponding SD error estimates. The star $(\star)$ denotes the value found by van Ovelen et al. (2009) for the Rockall Bank

web modelling study of van Oevelen et al. (2009) for the deeper CWC ecosystem on the Rockall Bank. Whilst there is a large difference in water depth between this and the study of van Ovelen et al. (2009), typical temperatures at the 2 sites are generally 2 to $3^{\circ} \mathrm{C}$ cooler at the Tisler Reef. This may, in part, compensate for the greater depth of Rockall, where warmer temperatures would increase the respiration rate. Overall, the comparable values provides a degree of confidence that our results are sensible and that the errors and assumptions associated with the respiration estimates are small enough to allow at least a first order respiration estimate for the Tisler CWC ecosystem.

Some variation of our oxygen uptake values may be due to errors in the methodology and related to the relative position of the measurement within the reef with respect to the mean residual flow direction, and also to aperiodic events such as the passage of water mass boundaries over the reef or the influence of other dynamical processes such as internal waves. Relative position within a reef structure with a variation of microhabitats and faunal components (e.g. live stands, dead coral and rubble) would likely alter oxygen uptake rates (e.g. Wild et al. 2009, Wagner et al. 2011), but the approach here was to assess a bulk respiration rate for the CWC ecosystem and provide a first order estimate. There was evidence for significant seasonal variability in oxygen uptake rates, as might be expected. The 2006 spring values were made before the onset of the main spring bloom, the preceding harsh winter having delayed the bloom that year (Lavaleye et al. 2009), and likely reflect the respiration level during the winter months, for which we have no measurements. The post-spring bloom maximum in oxygen uptake rates is not surprising, given the high flux of POM to the sea floor at that time (Lavaleye et al. 2009). High autumn values, which followed relatively low mid-summer rates, had a relatively large error associated with them, related to the subtraction of the long-term variability in oxygen values. These higher values, however, may also reflect the warmer temperatures that occur in the autumn and also a late phytoplankton bloom and a concomitant increase in abundance of zooplankton that would expected at that time in this region (Båmstedt 2000).

The values in Table 2 reflect reasonable seasonal variation in oxygen uptake, given the measurements were made at contrasting seasonal periods. Assuming that the early spring observations (Deployments $1 \mathrm{a}$ and $1 \mathrm{~b}$ ) reflect winter respiration rates (for which we have no data), then weighted mean values of $37.1 \mathrm{mmol} \mathrm{O}_{2} \mathrm{~m}^{-2} \mathrm{~d}^{-1}$ and $28.5 \mathrm{mmol} \mathrm{C} \mathrm{m}^{-2} \mathrm{~d}^{-1}$ are obtained, comparable to the mean deposition flux of POC of $38 \mathrm{mmol} \mathrm{C} \mathrm{m} \mathrm{m}^{-2} \mathrm{~d}^{-1}$ found by Wagner et al. (2011), which was also calculated assuming a uniform concentration of material in the lower $3 \mathrm{~m}$ of the water column. Using the average values, a resultant mean annual carbon equivalent respiration for the Tisler Reef, therefore, is $\sim 118 \mathrm{~g} \mathrm{C} \mathrm{m}^{-2} \mathrm{yr}^{-1}$ at the reef (assuming no respiration over $65 \mathrm{~d}$ ). This value is high, 3 times that measured below the halocline in the nearby shallow southeastern Kattegat (31-49 m water depth) over a period of $\sim 250 \mathrm{~d}\left(38.3 \mathrm{~g} \mathrm{C} \mathrm{m}^{-2}\right.$; Granéli 1992), and suggests that the Tisler CWC ecosystem plays a significant local role in carbon cycling.

CWC reef systems are abundant along the Norwegian margin and all of similar form with a combination of live stands, dead coral and associated rubble, although reef morphology may vary in isolated small mounds, situated on sill structures or on other small topographic features. Based on multibeam surveys, observations from fishermen and other desk-based research, Mortensen et al. (2001) report a coverage of Lophelia pertusa reef systems covering $35 \mathrm{~km}^{2}$ within a region of $600 \mathrm{~km}^{2}$ in the vicinity of the Halten gas pipeline. This represents coverage of about $6 \%$. If CWC reef systems are associated with high carbon turnover rates, as inferred in the present study, then the relatively large coverage of such 
ecosystems along the Norwegian margin may represent a regional 'hotspot' of carbon cycling. Other regions such as the extensive carbonate mound regions of the Rockall Trough (NE Atlantic) may also be such hotspots (e.g. van Ovelen et al. 2009).

High inferred values of carbon respiration at CWCs indicate the likely significance of CWC to carbon (and nutrient) cycling in this region and probably for other regions where coral is abundant, e.g. NE Atlantic/Rockall Trough (Freiwald 2002, Roberts et al. 2003, van Weering et al. 2003). CWC ecosystems are under threat from both anthropogenic influence and climate change. For example, large regions of Norwegian coral have been impacted by fishery activities (Fosså et al. 2002). In addition, ocean acidification is a major threat to cold water corals (Orr et al. 2005, Turley et al. 2007). Therefore, loss of CWCs may significantly affect the carbon turnover and may create a perturbation in the local carbon cycle, as well as impacting other ecosystem services provided by the benthos.

Acknowledgements. We acknowledge J. Fosså for useful discussions and 3 anonymous referees for constructive comments on an earlier version of the manuscript. We are grateful to the Master and crew of the 'Nereis' for assistance at sea. We also thank M. Johnson (Ryan Institute) for advice on the significance of the statistical fits. The research leading to these results has received funding from the European Community's Seventh Framework Programme (FP7/2007-2013) under the HERMIONE project, grant agreement No. 226354 and previously by the HERMES (EC contract GOCE-CT-2005-511234) project, funded by the European Commission.

\section{LITERATURE CITED}

Andersson L, Rydberg L (1988) Trends in nutrient and oxygen conditions within the Kattegat: effects of local nutrient supply. Estuar Coast Shelf Sci 26:559-579

> Andersson L, Rydberg L (1993) Exchange of water and nutrients between the Skagerrak and Kattegat. Estuar Coast Shelf Sci 36:159-181

Andersson JH, Wijsman JWM, Herman PMJ, Middelburg JJ, Soetaert K, Heip CHR (2004) Respiration patterns in the deep ocean. Geophys Res Lett 31:L03304, doi:10. 1029/2003GL018756

Båmstedt U (2000) Life cycle, seasonal vertical distribution and feeding of Calanus finmarchicus in Skagerrak coastal water. Mar Biol 13:279-289

> Bett BJ (2001) UK Atlantic margin environmental survey: introduction and overview of bathyal benthic ecology. Cont Shelf Res 21:917-956

> Davies AJ, Wisshak M, Orr JC, Roberts JM (2008) Predicting suitable habitat for the cold-water coral Lophelia pertusa (Scleractinia). Deep-Sea Res 55:1048-1062

> Duineveld G, Lavaleye M, Berghuis E (2004) Particle flux and food supply to a seamount cold-water coral commu- nity (Galicia Bank, NW Spain). Mar Ecol Prog Ser 277: $13-23$

Duineveld GCA, Lavaleye M, Bergman MJN, de Stigter $H$, Mienis F (2007) Trophic structure of a cold-water coral mound community (Rockall Bank, NE Atlantic) in relation to the near-bottom particle supply and current regime. Bull Mar Sci 81:449-467

Fosså JH, Mortensen PB, Furevik DM (2002) The deepwater coral Lophelia pertusa in Norwegian waters: distribution and fishery impacts. Hydrobiologia 471:1-12

Frederiksen R, Jensen A, Westerberg H (1992) The distribution of the scleractinian coral Lophelia pertusa around the Faeroe Islands and the relation to internal tidal mixing. Sarsia 77:157-171

Freiwald A (2002) Reef forming cold water corals. In: Wefer G, Billett D, Hebblen D, Jorgensen BB, Schluter M, van Weering $\mathrm{T}$ (eds) Ocean margin systems. SpringerVerlag, Berlin, p 365-385

Freiwald A, Huhnerbach V, Lindberg B, Wilson JB, Campbell J (2002) The Sula Reef complex, Norwegian shelf. Facies 47:179-200

Genin A, Dayton PK, Lonsdale PF, Speiss FN (1986) Corals on seamount peaks provides evidence of current acceleration over deep-sea topography. Nature 322:59-61

Giles H, Pilditch CA, Nodder SD, Zeldisc JR, Currie K (2007) Benthic oxygen fluxes and sediment properties on the northeastern New Zealand continental shelf. Cont Shelf Res 27:2373-2388

Granéli W (1992) Below halocline oxygen consumption in the Kategat. Hydrobiologia 235-236:303-310

Guihen D (2010) Benthic dynamics and biophsyical interactions at Tisler cold-water coral reef. PhD thesis, National University of Ireland, Galway

Johnson LG, Nilsson PG, Floruta F, Lundälv T (2004) Distributional patterns of macro- and megafauna associated with a reef of the cold-water coral Lophelia pertusa on the Swedish west coast. Mar Ecol Prog Ser 284:163-171

Kiriakoulakis K, Bett BJ, White M, Wolff GA (2004) Organic biogeochemistry of the Darwin Mounds, a deep-water coral ecosystem, of the NE Atlantic. Deep-Sea Res 51: 1937-1954

> Lavaleye M, Duineveld G, Lundälv T, White M, Guihen D, Kiriakoulakis K, Wolff GA (2009) Cold-water corals on the Tisler Reef. Preliminary observations on a dynamic reef environment. Oceanography 22:76-84

Ljøen R (1962) L Om hydrografiske forhold I Skagerak og den nordøstlige del av Nordsjøen, og etydning for fordelingen av brislingegg og yngel. Fisken Havel 1:15-23

> Mecking S, Warner MJ, Bullister JL (2006) Temporal changes in pCFC-12 ages and AOU along 2 hydrographic sections in the eastern subtropical North Pacific. Deep-Sea Res I 53:169-187

Mortensen PB, Hovland M, Brattegard T, Farestveit R (1995) Deep water bioherms of the scleractinian coral Lophelia pertusa (L.) at $64^{\circ} \mathrm{N}$ on the Norwegian shelf: structure and associated megafauna. Sarsia 80:145-158

Mortensen PB, Hovland T, Fosså JH, Furevik DM (2001) Distribution, abundance and size of Lophelia pertusa coral reefs in mid-Norway in relation to seabed characteristics. J Mar Biol Assoc UK 81:581-597

Orr JC, Fabry VJ, Aumont O, Bopp L and others (2005) Anthropogenic ocean acidification over the 21st century and its impact on calcifying organisms. Nature 437: $681-686$ 
Roberts JM, Long D, Wilson JB, Mortensen PB, Gage JD (2003) The cold coral Lophelia pertusa (Scleractinia) and enigmatic seabed mounds along the north-east Atlantic margin; Are they related? Mar Pollut Bull 46:7-20

Roberts JM, Wheeler AJ, Freiwald A (2006) Reefs of the deep: the biology and geology of cold-water coral ecosystems. Science 312:543-547

Thiem O, Ravagnan E, Fosså JH, Berntsen J (2006) Food supply mechanisms for cold-water corals along a continental shelf edge. J Mar Syst 60:207-219

Turley CM, Roberts JM, Guinotte JM (2007) Corals in deepwater: Will the unseen hand of ocean acidification destroy cold-water ecosystems? Coral Reefs 26:445-448

van Oevelen D, Duineveld G, Lavaleye M (2009) The coldwater coral community as a hot spot for carbon cycling on continental margins: a food-web analysis from Rockall Bank (northeast Atlantic). Limnol Oceanogr 54:1829-1844 van Weering TCE, de Haas $H$, de Stigter $H$, LykkeAnderson H, Kouvaev I (2003) Structure and development of giant carbonate mounds at the SW and SE Rock- all Trough margins, NE Atlantic Ocean. Mar Geol 198: 67-81

- Wagner $\mathrm{H}$, Pursur A, Thomsen L, Jesus CC, Lundalv $\mathrm{T}$ (2011) Particulate organic matter fluxes and hydrodynamics at the Tisler cold-water coral reef. J Mar Syst 85: $19-29$

White M (2007) Benthic dynamics at the carbonate mound regions of the Porcupine Sea Bight continental margin. Int J Earth Sci 96:1-9

White M, Mohn C, de Stigter H, Mottram G (2005) Deep water coral development as a function of hydrodynamics and surface productivity around the submarine banks of the Rockall Trough, NE Atlantic. In: Freiwald A, Roberts JM (eds) Cold-water corals and ecosystems. SpringerVerlag, Berlin, p 503-514

Wild C, Wehrmann LM, Mayr C, Schottner SI, Allers E, Lundalv T (2009) Microbial degradation of cold-water coralderived organic matter: potential implication for organic $\mathrm{C}$ cycling in the water column above Tisler Reeef. Aquat Biol 7:71-80

Submitted: July 28, 2011; Accepted: June 19, 2012

Proofs received from author(s): September 18, 2012
Editorial responsibility: Karen Miller,

Hobart, Tasmania, Australia 